\title{
User Experience in an Automated World
}

Palanque, Philippe; Campos, Pedro F.; Abdelnour-Nocera, José; Clemmensen, Torkil; Roto, Virpi

Document Version

Accepted author manuscript

Published in:

Human-Computer Interaction - INTERACT 2019

DOI:

10.1007/978-3-030-29390-1_67

Publication date:

2019

License

Unspecified

Citation for published version (APA):

Palanque, P., Campos, P. F., Abdelnour-Nocera, J., Clemmensen, T., \& Roto, V. (2019). User Experience in an Automated World. In D. Lamas, F. Loizides, L. Nacke, H. Petrie, M. Winckler, \& P. Zaphiris (Eds.), HumanComputer Interaction - INTERACT 2019: Proceedings of the 17th IFIP TC 13 International Conference, Part IV (pp. 706-710). Springer. Lecture Notes in Computer Science Vol. 11749 https://doi.org/10.1007/978-3-03029390-1_67

Link to publication in CBS Research Portal

\section{General rights}

Copyright and moral rights for the publications made accessible in the public portal are retained by the authors and/or other copyright owners and it is a condition of accessing publications that users recognise and abide by the legal requirements associated with these rights.

Take down policy

If you believe that this document breaches copyright please contact us (research.lib@cbs.dk) providing details, and we will remove access to the work immediately and investigate your claim.

Download date: 26. Apr. 2023
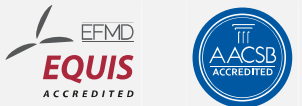


\section{User Experience in an Automated World \\ Philippe Palanque, Pedro F. Campos, José Abdelnour-Nocera, Torkil Clemmensen, and Virpi Roto}

Article in proceedings (Accepted version*)

\section{Please cite this article as:}

Palanque, P., Campos, P. F., Abdelnour-Nocera, J., Clemmensen, T., \& Roto, V. (2019). User Experience in an Automated World. I D. Lamas, F. Loizides, L. Nacke, H. Petrie, M. Winckler, \& P. Zaphiris (red.), HumanComputer Interaction - INTERACT 2019: Proceedings of the 17th IFIP TC I3 International Conference, Part IVIs. 706-710). Springer. Lecture Notes in Computer Science, Bind. 11749 https://doi.org/10.1007/978-3-03029390-1_67

This is a post-peer-review, pre-copyedit version of an article published in Human-Computer Interaction INTERACT 2019: Proceedings of the 17th IFIP TC 13 International Conference, Part IV. The final authenticated version is available online at:

口Ol: https://doi.org/10.1007/978-3-030-29390-1_67

* This version of the article has been accepted for publication and undergone full peer review but has not been through the copyediting, typesetting, pagination and proofreading process, which may lead to differences between this version and the publisher's final version AKA Version of Record. 


\title{
User Experience in an Automated World
}

\author{
Philippe Palanque ${ }^{4(\bowtie)}$, Pedro F. Campos ${ }^{2}$, José Abdelnour Nocera ${ }^{1,2}$, \\ Torkil Clemmensen ${ }^{3}$, and Virpi Roto ${ }^{5}$ \\ ${ }^{1}$ University of West London, London, UK \\ jose.abdelnour-nocera@uwl.ac.uk \\ 2 Madeira-ITI, University of Madeira, Funchal, Portugal \\ pedro.campos@m-iti.org \\ 3 Department of Digitalization, Copenhagen Business School, \\ Frederiksberg, Denmark \\ tc.digi@cbs.dk \\ ${ }^{4}$ ICS-IRIT, Université Paul Sabatier Toulouse 3, Toulouse, France \\ palanque@irit.fr \\ 5 School of Arts, Design and Architecture, Aalto University, Helsinki, Finland \\ virpi.roto@aalto.fi
}

\begin{abstract}
The aim of this panel is to raise awareness and to foster discussions around the notions of Automation and User Experience and their interplay in the design, development, evaluation and deployment of interactive systems. User Experience is taken in its broad meaning as defined in the white paper of https:// www.allaboutux.org/ [1]. As for automation we consider here its wide perspective as proposed in [4] - The Seven Deadly Myths of "Autonomous Systems". In a time where there is strong push towards more and more automation in our daily life, the panel will question the impact of such trend on users' experiences in multiple contexts such as work, entertainment, learning, as well as question other important emerging issues such as ethics, engagement and automation rationale.
\end{abstract}

Keywords: Automation - User Experience · Engagement • Interaction design • Work

\section{Introduction and Questions}

Interaction design for work engagement has lately started to gather more attention, especially in designing interactive systems for employees at their workplace. As algorithms and machines take over parts of the work which were previously performed manually, a larger part of the work engagement is dependent on the employees' experience with (partly-) automated systems. Is automation making work less interesting or more engaging? How to improve work engagement through automation? How to optimally allocate work between humans and automation? How to maintain operators' vigilance in highly automated environments? How to support situation and/or automation awareness? How to evaluate the impact of automation on work engagement? How increased automation raises ethics issues? This panel aims to discuss these questions and to provide a forum for researchers, practitioners, and anyone engaged in 
work analysis and interaction design for the workplace. We will discuss tools, procedures, and professional competences needed for designing and evaluating engaging automation in workplace contexts.

\section{Panel Topics and Objectives}

The panel will bring diverse (potentially conflicting) perspectives on User Experience in a world that embeds increasing automation.

While early approaches in automation were focusing on allocating basic functions to the best player (e.g. Fitts' approach Machine Are Better At - Men Are Better At) [7], this panel focuses on the combined use of the concepts of automation within interactive systems development. The current push in automation is towards fully autonomous systems (such as google cars or robotic software agents in the case-handling processes of public service provision). This push raises critical issues such as: how to make it possible for users to foresee future states of the automation, how to disengage automation or how to make sure that users are able to take over when automation fails, and how to make sure that the highly qualified human does not completely loose interest in the automated processes.... When higher automation levels are considered, users' activity gets closer to supervision, which is a different interaction paradigm deeply impacting user experience. One question that the panel will address is "how to keep employees motivated when automation pervades the workplace?" However, recent studies [13] have demonstrated that very limited research work has been carried out on UX aspects in work environments, surprisingly leaving this aspect to practitioners. One question to consider is "why is there limited research work at the intersection of automation, UX and work?".

When designing for User Experience, the focus is mostly put on users' emotions, aesthetics, users' stimulation, affinity towards a certain product or service as well as other aspect. Sometimes UX is performed overlooking usability concepts such as efficiency and effectiveness. In domains such as entertainment, UX is key and automation serves as a mean to improve UX. One question that the panel will consider is: "is there a UX in automation that goes beyond games?"

\section{Panelists}

The panel will be moderated by Pedro F. Campos who will be checking fairness and politeness in the arguments developed by the panelists. Beyond, he will also ensure that space is left for interaction with the audience.

\section{Philippe Palanque (convener) - Automation and UX in Safety Critical Systems}

In safety critical systems automation is a first class citizen with a very polymorphic nature. Autonomous systems can be there to protect the system (e.g. Traffic Collision Avoidance Systems), to increase comfort by migrating actions to an autonomous system (e.g. autopilot) but also to increase operations when conditions are not met (e.g. auto land system). UX is a second class citizen as major focus in design is on overall safety of operations. 
Philippe is Professor in Computer Science at the University Toulouse 3. He is working on formal methods for engineering interactive systems and the application of such techniques to Higher Automation Levels in the field of Air Traffic Management, Interactive Cockpits of Large Civil Aircrafts [3] and Satellite Ground Segments. He was chair of (Application and Theories of Automation in Command and Control Systems) ATACCS 2015 conference and co-organized a workshop on Automation and autonomous vehicles [9]. Philippe has also co-organized several courses on automation (e.g. [10]) and has long been active in SIGCHI and other international societies such as IFIP.

\section{Pedro F. Campos (moderator) - Automation and UX in Physical Artefacts}

How can automation become embedded into the fabrics of everyday life in such a way that it augments human capabilities, as opposed to simply automate repetitive tasks or oversee human action in critical situations? One possible research approach is based on taking concepts from behavioral economics (e.g. nudging) and exploiting our innate cognitive biases to guide users' behavior towards the desired UX goals.

Pedro is Associate Professor with Habilitation at the University of Madeira, Portugal, and scientific director of the Madeira Interactive Technologies Institute. Pedro leads the Experience Augmentation group, bridging cognitive augmentation with experience design and exploring novel systems to augment human cognition and to design better user experiences. He has co-organized many workshops [15] and has also hosted conferences on work engagement and automation [2].

\section{José Abdelnour Nocera - Automation, User Experience and Ethics}

There a number of ethical considerations when choosing how and what to automate about work from a designer's perspective. These have to do with workers' and organizations' abilities to understand and experience the rationale for automating. In my short statement I will present these issues through ongoing case studies in a UK airport and an Indian fishing village.

José is Associate Professor in Sociotechnical Design and Head of the Sociotechnical Centre for Innovation and User Experience at the University of West London. He is the current Chair for IFIP TC 13.8 working group in Interaction Design for International Development as well as Chair for the British Computer Society Sociotechnical Specialist Group. His interests lie in the sociotechnical and cultural aspects of systems design, development and use. In pursuing these interests, he has been involved as researcher and consultant in several projects in the UK and overseas in the domains of mHealth, e-learning, social development, e-commerce, e-governance and enterprise resource planning systems. Dr. Abdelnour-Nocera gained an MSc in Social Psychology from Simon Bolivar University, Venezuela and a $\mathrm{PhD}$ in Computing from The Open University, UK.

\section{Torkil Clemmensen - UX and Automation in SMEs}

Automation is currently flooding SMEs (small and medium sized enterprises) to help develop their capacity to produce in a globalized world and ensure workers' wellbeing. One example of this is the use of collaborative robots' to extend and transform SME's manufacturing of specialized products, and to automate workers' repetitive work sequences. However, the collaborative robot requires specialized knowledge in 
workers, thus reduces flexibility in its application, and it imposes its limitations and rhythm onto the workflow. Given that the human worker is supposed to collaborate with and not 'experience' the robot, should we as researchers continue to talk about workers' user experiences of automation?

Torkil Clemmensen, PhD, Professor at Department of IT Management, Copenhagen Business School, Denmark. His interest is in Human-Computer Interaction, in particular psychology as a science of design. As Danish representative in IFIP (International Federation of Information Processing) TC 13 (Technical committee on HumanComputer Interaction), and vice-chair of Working Group 13.6 on Human Work Interaction Design (HWID), he co-organizes a series of international working conferences on work analysis and usability/user experiences in organizational, human, social, cultural, and technological contexts. The long term aim is to develop a Human Work Interaction Design (HWID) framework as an easy-to-use development platform for a multitude of analytical tools for socio-technical interventions in various work domains $[1,6]$. One recent example of this is a running project on using a HWID approach to empower workers to co-design their user experiences and collaboration with collaborative robots in a Danish glass processing SME.

\section{Virpi Roto - UX and Automation in Remote Operations and Industry}

Introducing AI systems in industry may look fancy from the technology perspective, but for me as a UX researcher, it looks like a jump back to 1970's: Suddenly, employees are the servants of the admirable computer systems again. As in the first wave of HCI, the focus is back on the human factors and ethical aspects of AI systems. I wish it will not take 30 years again to see that good user experience is in the core of computer systems, also in AI systems with high levels of automation.

Virpi Roto is a Professor of Practice in Experience Design in Aalto University, Finland. She has studied user experience of consumer products in Nokia Research Center for 15 years and UX of interactive products and services in heavy industry contexts for 8 years. One of the research projects study industrial automation, bringing the human perspectives such as UX, engagement, and ethics on the table.

\section{Audience and Prerequisite}

This panel is open to researchers, practitioners, educators and students of all experience levels. We especially welcome attendees who would like to debate the topics presented above. We also expect attendees to report on their experiences with design, development of use of automation within interactive technologies.

\section{References}

1. Abdelnour-Nocera, J., Clemmensen, T.: Theorizing about socio-technical approaches to HCI. In: Barricelli, B.R., et al. (eds.) HWID 2018. IAICT, vol. 544, pp. 242-262. Springer, Cham (2019). https://doi.org/10.1007/978-3-030-05297-3_17

2. Barricelli, B., et al.: Human-Work Interaction Design (HWID'18) - Designing Engaging Automation. IFIP Advances in Information and Communication Technology, vol. 544. Springer, Heidelberg (2019). https://doi.org/10.1007/978-3-030-05297-3 
3. Bernhaupt, R., Cronel, M., Manciet, F., Martinie, C., Palanque, P.: Transparent automation for assessing and designing better interactions between operators and partly-autonomous interactive systems. In: ATACCS 2015, pp. 129-139. ACM DL (2015)

4. Bradshaw, J., Hoffman, R., Woods, D., Johnson, M.: The seven deadly myths of "autonomous systems". IEEE Intell. Syst. 28(3), 54-61 (2013)

5. Cavestro, W.: Beyond the deskilling controversy. Comput. Integr. Manuf. Syst. 3(1), 38-46 (1990)

6. Clemmensen, T.: Designing a simple folder structure for a complex domain. Hum. Technol. Interdisc. J. Hum. ICT Environ. 7(3), 216-249 (2011)

7. Fitts, P.M.: Human Engineering for an Effective Air Navigation and Traffic Control System. National Research Council, Washington (1951)

8. Mackworth, N.H.: The breakdown of vigilance during prolonged visual search. Q. J. Exp. Psychol. 1, 6-21 (1948)

9. Meschtscherjakov, A., et al.: Interacting with autonomous vehicles: learning from other domains. In: CHI Conference (CHI EA 2018). ACM DL (2018)

10. Palanque, P., Martinie, C., Fayollas, C.: Automation: danger or opportunity? Designing and assessing automation for interactive systems. In: CHI Conference Extended Abstracts (CHI EA 2017). ACM DL (2017)

11. Parasuraman, R., Sheridan, T.B., Wickens, C.D.: A model for types and levels of human interaction with automation. IEEE Trans. Syst. Man Cybern. Part A Syst. Hum. 30(3), 286297 (2000)

12. Roto, V., Law, E., Vermeeren, A., Hoonhout, J. (eds).: User experience white paper bringing clarity to the concept of user experience. In: Outcome of the Dagstuhl Seminar on Demarcating User Experience, Germany (2011). http://www.allaboutux.org/uxwhitepaper

13. Roto, V., Palanque, P., Karvonen, H.: Engaging automation at work - a literature review. In: Barricelli, B.R., et al. (eds.) HWID 2018. IAICT, vol. 544, pp. 158-172. Springer, Cham (2019). https://doi.org/10.1007/978-3-030-05297-3_11

14. Yerkes, R.M., Dodson, J.D.: The relation of strength of stimulus to rapidity of habitformation. J. Comp. Neurol. Psychol. 18, 459-482 (1908) 